\title{
EFL Students' and Teachers' Attitudes toward Foreign Language Speaking Anxiety: A look at NESTs and Non-NESTs
}

\author{
Turgay HAN ${ }^{1}$, Ahmet Serkan Tanriöver ${ }^{2} \&$ Özgür Şahan ${ }^{2}$ \\ ${ }^{1}$ Dept. Of English Language and Literature, Faculty of Science and Letters, Kafkas University, Kars, Turkey \\ ${ }^{2}$ School of Foreign Languages, Bursa Technical University, Bursa, Turkey \\ Correspondence: Turgay HAN, Kafkas Üniversitesi, Fen Edebiyat Fakültesi, İngiliz Dili ve Edebiyatı Bölümü, \\ 36100, Kars, Turkey. Tel: 90-474-7225-1150/3067. E-mail: turgayhan@kafkas.edu.tr
}

Received: July 3, 2015 Accepted: September 14, 2015 Online Published: February 18, 2016

doi:10.5539/ies.v9n3p1 URL: http://dx.doi.org/10.5539/ies.v9n3p1

\begin{abstract}
Native English Speaking Teachers (NESTs) have been employed in various English language teaching (ELT) positions and departments at private and state universities in Turkey, particularly over the last three decades. However, undergraduate EFL students' attitudes toward NESTs and Non-Native English Speaking Teachers (Non-NESTs) remain seriously under-investigated. The purpose of this study is to examine the impact of communication classes given by NESTs and Non-NESTs on students' foreign language speaking anxiety (FLSA). Forty-eight undergraduate EFL students attending communication classes taught by (American) NESTs and (Turkish) Non-NESTs were given a questionnaire to examine their attitudes toward foreign language speaking anxiety (FLSA). Further, a sub-sample of students was interviewed to investigate their feelings, beliefs and opinions about the relationship between the FLSA they experienced and their communication classes given by NESTs and Non-NESTs. Similarly, the teachers were interviewed to examine their feelings about the FLSA their students experience in their communication classes. Quantitatively, the results showed no significant difference in attitude toward FLSA between the students who attended classes taught by NESTs and Non-NESTs, although a significant difference was observed between the two classes taught by Non-NESTs. Further, female and male students did not differ significantly in terms of attitudes toward FLSA in NESTs' and Non-NESTs' classes. The qualitative findings revealed that both teachers and students had positive attitudes toward mistakes made during the oral production of the foreign language (FL). Finally, the correction strategies employed by the teachers in the classroom are believed to have an impact on student attitudes toward FLSA.
\end{abstract}

Keywords: foreign language speaking anxiety, communication class, native English speaking teachers, non-native English speaking teachers

\section{Introduction}

Researchers in the fields of English language teaching (ELT) and applied linguistics have found that foreign language speaking (FLS) in an instructional setting is considered to be an anxiety-provoking activity since a student has to perform a series of complex cognitive, intellectual and functional operations and struggle with numerous elements such as instructor-effect, peer-effect, content of speaking, classroom atmosphere, student population, course materials, type (face-to-face speaking, group discussion, etc.) and purpose (informative, persuasive, and entertaining purposes) of conversational task, and instructor's accent before EFL audience in the classroom (Onwuegbuzie, Bailey, \& Daley, 1999). Environmental, social, cultural, psychological, and biological factors may also cause a certain level of FLSA and therefore prevent FL students from proficiently and sufficiently performing verbal/oral tasks in English classes (Aida, 1994; Horwitz \& Cope, 1986; MacIntyre \& Gardner, 1989; Young, 1991).

Scholars in the fields of ELT and applied linguistics have carried out comprehensive research on FLA for several decades. Scovel (1978) is the earliest scholar to use the term 'anxiety' in Second Language Acquisition (SLA) and Foreign Language Learning (FLL) contexts. Eight years after Scovel's research on FLA, Horwitz et al. (1986) conducted a research on the same issue and developed the Foreign Language Classroom Anxiety Scale (FLCAS), which has been widely used by researchers of FLA. MacIntyre and Gardner (1989, 1991a, 1994a, 1994b) contributed to the field by examining the structure, mechanism, and function of anxiety in FLL and its effects on students' in-class achievement. FLA was primarily studied as communication apprehension (CA) 
(Horwitz et al., 1986; MacIntyre \& Gardner, 1991b; Young, 1990), test anxiety (TA) (Daly, 1991; Horwitz et al., 1986; Young, 1991), and fear of negative evaluation (FNE) (Aida, 1994; Horwitz et al., 1986; Young, 1990).

The potential sources of FLA were also identified in several studies (Aida, 1994; Ely, 1986; Gardner, Lalonde, Moorcroft, \& Evers, 1987; Maclntyre \& Gardner, 1989, 1991b; Phillips, 1992; Young, 1986). Young (1991) defined six main potential sources of FLA: a) personal and interpersonal anxieties (e.g., communication apprehension, self-esteem, self-confidence), b) instructor beliefs about language teaching, c) learner beliefs about language learning, d) classroom procedures (e.g., speaking in front of peers, performing whole-class conversations, participating in group discussions), e) instructor-learner interactions (e.g., teachers' harsh manner of correcting student mistakes), and f) testing. Adult language learners, for example, benefit from their mature linguistic knowledge and perception; however, their immature linguistic systems in the target language prevent them from expressing themselves comprehensively (Horwitz et al., 1986). They also feel uncomfortable and anxious while learning and using a foreign language due to their peers' competitive attitudes and negative evaluation (Bailey, 1983). They also tend to think that their language ability is lower than their peers' (Price, 1991). Further, foreign language anxiety about learning and using a foreign language is considered to be apparent at both lower and advanced levels of language competencies (Tóth, 2011).

Speaking a foreign/second language in a classroom atmosphere is also considered to be one of the greatest sources of anxiety (Horwitz, 2001; Gregersen \& Horwitz, 2002; Liu, 2009). Teacher attitude toward the FLL processes and inappropriate error correction methods are other factors that negatively affect FLSA (Koch \& Terrel, 1991; Young, 1991). Individual factors such as age (Krashen, Long, \& Scarcella, 1982: Penfield \& Roberts, 1959), aptitude (Carroll, 1981; Pimsleur, 1966), motivation (Clément, 1986; Gardner \& Lambert, 1972), beliefs (Horwitz, 1987; Onwuegbuzie, Bailey, \& Daley, 1999), and personality (Guiora et al., 1972) are also among the major factors that cause FLSA. Further, gender is another crucial factor affecting students' FLSA. For example, several studies indicated that particularly while speaking (Aida, 1994; Ngidi \& Siberya, 2003; Sarıgül, 2000) female learners are more anxious than male learners potentially due to cultural and societal characteristics (Wilson, 2006). Finally, teacher expectations toward students, classmates' L2 proficiency, and the perceptions concerning their own L2 competence (inaccuracies, limited fluency, reaction time, quality of self-expression, etc.) can cause FLA (Tóth, 2011). Regarding classroom atmosphere, Kondo and Ling (2004) reported that more than half of foreign language learners experienced different types and levels of FLA in the classroom. An anxiety-provoking classroom atmosphere hinders FLL processes by negatively influencing student perceptions of FLL (MacIntyre \& Gardner, 1989; Tobias 1979, 1980, 1989). Researchers argued that FLA limits student performance (Horwitz, 1991; Worde, 1998; Kondo \& Ling, 2004). Horwitz et al. (1986) found that students with high anxiety levels have difficulty in speaking, comprehending, and producing sounds and avoid participating in oral activities in the target language. It is estimated that there is a negative correlation between FLA and classroom performance (e.g. course grades) (Aida, 1994; Tucker \& Genesee, 1976; Horwitz et al., 1986; Schwarzer, 1986; Young, 1986; MacIntyre \& Gardner, 1989, 1991b). Phillips (1992) also examined the inverse relationship between FL students' oral exam scores and their anxiety level. FLSA also affects foreign language fluency (Krashen, 1981; MacIntyre \& Gardner, 1991b). To overcome FLSA, it is suggested that students should participate in self-directed cognitive tasks, as FLL is a cognitive activity that involves encoding, storage, and retrieval processes (MacIntyre, 1995). Additionally, self-awareness interferes with the language performance of anxious learners (Tobias, 1986).

As stated above, instructors' beliefs about language teaching are a potential source of FLA (Young, 1991). In this sense, teacher's first language (L1) background may be a factor that increases students' FLSA. In his book entitled The Non-Native Teacher, Medgyes (1994, p. 27) points out that although NESTs and Non-NESTs are two distinct parties in terms of language background, language proficiency, teaching behavior, ethnicity, and social and political status, one group should not be favored over the other in terms of teaching quality, educational approaches, and teaching methods. Moreover, both parties should be perceived and treated in accordance with their professional virtue. Additionally, the strengths of Non-NESTs have led to the understanding that neither NESTs nor Non-NESTs are superior but simply different from each other (Alptekin \& Alptekin, 1984). The prevailing trend of perceiving NESTs as ideal teachers is favored by a Chomskyan viewpoint that regards NESTs as ideal speaker-listeners who know the language perfectly (Canagarajah, 1999). NESTs are believed to be very competent in their mother tongue such as pronunciation and fluency; however, Non-NESTs' are well-prepared for the course, more empathetic and more knowledgeable than NESTs about how to teach English and the language itself (Cook, 1999). On the other hand, teachers should pay attention to the impact of FLA on the anxiety experienced by learners in the classroom atmosphere (Horwitz, 2001)

Non-NESTs have a distinctive characteristic that provides them with an overwhelming advantage over NESTs: 
they are successful language learner models who view FLL from the students' perspectives. Furthermore, this advantage becomes more pronounced if FLL takes place in the teacher's home country where he or she has the chance to communicate with students in L1, which contributes a worry-free classroom atmosphere for students (Nemtchinova, 2005). Canagarajah (1999) states that although it is commonly believed that English should be the only language used in an FL context, some researchers focus on the cognitive and pedagogical benefits of using L1 in SL/FL contexts. However, Arva and Medgyes (2000) suggest that a majority of FL students prefer to be taught communication (speaking) skills by a NEST who does not speak learners' L1 in order to increase student motivation.

As the above literature has indicated, to the best of our knowledge, no research has been conducted on the impact of EFL teachers' L1 background on students' attitudes toward FLSA. This study aims at bridging this research gap by examining the communication classes taught by (American) NESTs and (Turkish L1 background) Non-NESTs in the Turkish undergraduate EFL context. The following research questions guided this study:

Quantitatively, the following two research questions were asked:

a) Does the communication teachers' L1 background impact EFL students' attitudes toward FLSA?

b) Is there any significant difference between male and female EFL students' attitudes toward FLSA in communication classes taught by NESTs and Non-NESTs?

Qualitatively, the following two research questions were asked:

a) How do the students feel about their FLSA in communication classes taught by NESTs and Non-NESTs?

b) What do the NESTs and Non-NESTs think about the FLSA that their students experience in their communication classes?

\section{Method}

\subsection{Setting and Participants}

The study was conducted at the preparatory program of a state university in Turkey where students learn English at four levels-A1, A2, B1 and B2-each of which covers 8 weeks of instruction. A convenience sampling strategy was followed for the student participants. The sample group included 48 engineering students in total who were learning English at the A1/Breakthrough level at the time of this study. Prior to the beginning of the study, the students were divided randomly into four classes for their coursework. Two of these four classes received speaking courses from NESTs while the other two received speaking courses from Non-NESTs. A total number of 33 participants were male and the remaining 15 students were female. They were placed in A1 level English language preparatory classrooms through a placement test at the beginning of the 2014-2015 academic year.

The two NESTs were from the USA while the two Non-NESTs were from Turkey who have Turkish L1 background. Each group included one female and one male teacher. Three of the teachers (two Non-NESTs and one NEST) were considered to be experts with their teaching experience over 10 years. One NEST and one Non-NEST held an MA degree in the field of English Language. However, the other NEST was TESOL certified and in her first year of teaching English. The Turkish teachers were in their third year at this institution; however, the American teachers were in their first year of working with the university. Both teacher groups gave their instruction based on the same curriculum and pacing calendar and by using the same materials.

\subsection{Data Collection Tools}

The questionnaire, adapted from Young (1990), was comprised of 24 items pertaining to students' attitude toward anxiety based on student preparedness and speaking-related communication activities. Given the students' low English proficiency, the questionnaire was administered to the students in their native language. The Turkish version of the questionnaire was translated by Bozavli and Gulmez (2012), and the $p$-value for the Turkish version was 0.70 , compared to the original questionnaire's $p$-value of 0.74 .

Further, semi-structured open-ended questions and face-to-face interviews were used to collect qualitative data from a sub-sample of 12 randomly selected students. The qualitative data were used to better understand the students' feelings and to supplement the quantitative data. In order to find out the teachers' feelings about speaking and anxiety, all the teachers also responded to open-ended questions. The participants' responses to the interview provided invaluable data to further understand speaking anxiety from a deeper perspective. Pseudonyms were used to protect the identity of participants while interpreting the qualitative data collected from teachers. 


\subsection{Data Collection Process}

The data was collected in three steps. First, the Turkish version of the questionnaire (Bozavli \& Gulmez, 2012) was given to $48 \mathrm{EFL}$ students during the last week of the first level (A1, week 8). Next, semi-structured face-to-face interviews were conducted with a sub-sample of 12 participants (e.g. three students from each teacher's classroom). The students were randomly selected from volunteers. Finally, NESTs and Non-NESTs were invited to respond to open-ended interview questions to examine their thoughts about speaking anxiety and to examine the strategies they use to make students feel comfortable during speaking-dominated communication activities.

\subsection{Data Analysis}

A series of inferential statistics was performed to analyze the quantitative data. Inferential statistics (e.g. Mann-Whitney U-test and Wilcoxon Signed Rank Test) were used to examine significant attitude differences toward FLSA and to compare the students' attitudes toward classes taught by NESTs and Non-NESTs.

As for qualitative data, the interviews were voice-recorded and transcribed for analysis in order to determine the main themes that students underlined about FLSA. Qualitative data were analyzed based on recurring themes according to the coding-classifying approach described by Gay and Airasian (2009). The texts of the interviews were coded and all the codes were reviewed until the redundant codes were eliminated. Then, the qualitative data were categorized into these codes in order to determine the key concepts that reflect the meaning attached to the qualitative data.

\section{Results}

\subsection{Quantitative Data Analysis}

Inferential statistics were conducted to analyze the quantitative data. They involve non-parametric paired samples t-tests and independent samples t-tests for EFL students' attitudes toward speaking anxiety obtained from the participants who attended lectures delivered by NEST and Non-NEST.

Table 1 and Table 2 present the Mann-Whitney U-test for independent samples conducted to examine the significant differences between male and female students' attitudes toward FLSA in communication classes taught by NESTs and Non-NESTs. Table 3 and Table 4 show the Mann-Whitney U-test results for male and female teachers' attitudes toward FLSA in classes taught by Non-NESTs (e.g. Köksal and Ayşe) and NESTs (e.g. Tom and Rebecca). Finally, Table 5 shows the Wilcoxon Signed Rank test for paired samples conducted to compare the significant differences of students' perception of EFL speaking anxiety in communication classes taught by NESTs and Non-NESTS.

Table 1. Mann-Whitney U-test results for male and female students' attitudes toward classes taught by NESTs

\begin{tabular}{lccccc}
\hline & $\mathrm{n}$ & Mean rank & $\mathrm{U}$ & $\mathrm{z}$ & Sig. (2-tailed) \\
\hline Male & 18 & 12.53 & 54.500 & -.974 & .330 \\
female & 8 & 15.69 & & &
\end{tabular}

Table 1 shows the Mann-Whitney U-test for independent samples conducted to examine the significant differences between male and female students' attitudes toward FLSA in communication classes taught by native lecturers. As Table 1 shows, there was no significant difference between males and females $(p<.05)$, although males received a higher mean rank score, indicating that the female and male EFL students have similar attitudes toward EFL speaking anxiety in communication classes taught by NESTs $(U=54.500 ; p=.330 ; p<0.05)$.

Table 2. Mann-Whitney U-test results for male and female students' attitudes toward classes taught by Non-NESTs

\begin{tabular}{cccccc}
\hline & $\mathrm{n}$ & Mean rank & $\mathrm{u}$ & $\mathrm{z}$ & Sig. (2-tailed) \\
\hline Male & 15 & 11.57 & & -.071 & .944 \\
female & 7 & 11.36 & 51.500 & & \\
\hline
\end{tabular}


Table 2 shows the Mann-Whitney U-test for independent samples conducted to examine the significant differences between male and female students' attitudes toward FLSA in communication classes taught by Non-NESTs. Similar to the results presented in Table 1, Table 2 shows that there was no significant difference between males and females $(\mathrm{p}<.05)$, indicating that male and female EFL students have similar attitudes toward EFL speaking anxiety in communication classes taught by Non-NESTs $(U=51.500 ; p=.944 ; p<0.05)$.

Table 3. Mann-Whitney U-test results for students' attitudes toward classes taught by the Non-NESTs (Köksal and Ayşe)

\begin{tabular}{cccccc}
\hline & $\mathrm{N}$ & Mean rank & $\mathrm{u}$ & $\mathrm{z}$ & Sig. (2-tailed) \\
\hline Köksal & 10 & 6.50 & \multirow{2}{*}{0,000} & -3.300 & .001 \\
Ayşe & 12 & 15.67 & & & \\
\hline
\end{tabular}

Table 3 shows the Mann-Whitney U-test for independent samples conducted to examine the significant differences between students' attitudes toward FLSA in communication classes taught by each Non-NEST. As Table 3 shows, there was a significant difference between student perception in the classes taught by Köksal and Ayşe $(p<.05)$. Also, Ayşe's class received higher mean rank scores, indicating that these Non-NESTs have some impact on their EFL students' attitudes toward speaking anxiety in communication classes $(U=10.000 ; p=.001$; $\mathrm{p}<0.05)$.

Table 4. Mann-Whitney U-test results for students' attitudes toward classes taught by the NESTs (Rebecca and Tom)

\begin{tabular}{lccccc}
\hline & $\mathrm{N}$ & Mean rank & $\mathrm{U}$ & $\mathrm{z}$ & Sig. (2-tailed) \\
\hline Rebecca & 12 & 12.54 & 72.500 & -.592 & .554 \\
Tom & 14 & 14.32 & & & \\
\hline
\end{tabular}

Table 4 shows the Mann-Whitney U-test for independent samples conducted to examine the significant differences between students' perception of FLSA in communication classes taught by each NEST. Contrary to the results presented in Table 3, Table 4 indicates that there was no significant difference in student perception between Rebecca's and Tom's classes $(p<.05)$. Although Tom's class received higher mean rank scores, the results indicate that these teachers have a similar impact on EFL students' attitudes toward speaking anxiety in communication classes $(\mathrm{U}=72.500 ; \mathrm{p}=.554 ; \mathrm{p}<0.05)$.

Table 5. Wilcoxon Signed Rank Test for comparing the students' attitudes toward classes taught by NESTs and Non-NESTs

\begin{tabular}{llccc}
\hline & & $\mathrm{N}$ & Mean Rank & $\mathrm{z}$ \\
\hline TOTAL & Negative Ranks & $11^{\mathrm{a}}$ & 9.32 & \multirow{2}{*}{-.093} \\
\cline { 2 - 4 } Positive Ranks & $9^{\mathrm{b}}$ & 11.94 & \\
\cline { 2 - 4 } Ties & $2^{\mathrm{c}}$ & & \\
\cline { 2 - 4 } Total & 22 & & \\
\hline
\end{tabular}

a. native teachers $<$ non-native teachers.

b. native teachers $>$ non-native teachers.

c. native teachers $=$ non-native teachers.

Table 5 shows the Wilcoxon Signed Rank test for paired samples conducted to compare the significant differences between students' perception of FLSA in communication classes taught by NESTs and Non-NESTs. 
As Table 5 shows, there was no significant difference in students' perception between the classes taught by NESTs and Non-NESTs $(p<.05)$, indicating that the first language background of these teachers does not have any impact on their EFL students' attitudes toward speaking anxiety in communication classes $(Z=-.093 ; p=.926$; $\mathrm{p}<0.05)$.

\subsection{Qualitative Data Analysis}

\subsubsection{Interview with Students}

Written and face-to-face interviews with a sub-sample of 12 participants were conducted to find out their implicit feelings and thoughts toward FLSA. The responses were analyzed based on common and recurring themes.

\section{When do the students experience FLSA?}

Students' responses concerning FLSA were categorized according to three themes: difficulty of English, fear of making mistakes, and teacher attitudes. When students were asked to indicate whether speaking English as a foreign language was a difficult task, the responses were split evenly. Six of the students reported that speaking in English is an easy task to accomplish if a) they were motivated instrumentally (e.g. for their professional life after their graduation), b) teachers created positive learning environments and had constructive attitudes, and c) opportunities were given for them to participate in speaking practice at school. The remaining 6 students stated that speaking English is challenging due to the limited exposure to the language's culture, unsuccessful foreign language teaching policies at primary and secondary education institutions, fear of making mistakes and self-confidence problems. Despite their negative attitudes, they strongly believed that they would succeed in speaking effectively in the end.

Students' FLSA appeared to be connected to making mistakes. Nine out of twelve students reported that they felt anxious because of the fear of making mistakes and the pressure their peers put on them. The students reported that their mistakes provoked responses such as teacher-correction, peer-correction and peer-teasing. However, these students dislike peer-correction especially for pronunciation mistakes and peer-teasing of their mistakes. Conversely, some students $(\mathrm{N}=4)$ reported that they did not fear making mistakes and they appreciated peer-correction, believing that making mistakes was an inherent part of human nature and their mistakes could function as positive input.

Finally, teacher attitude appeared to have an impact on students' FLSA. Some students $(\mathrm{N}=4)$ believed that their teachers' negative attitudes toward mistakes demotivated them. Further, two of the students stated that both positive teacher attitudes and comfortable learning environments suppressed their initial FLSA. When the participants were asked to indicate their opinions about teacher-correction in speaking classes, all of the students affirmed that they would prefer teachers to correct their mistakes although there was a discrepancy about whether it should be immediate or delayed.

\section{What do the students identify as the sources of FLSA?}

The students were asked to identify common sources of FLSA. Regarding their anxiety stemming from a variety of sources, especially the fear of making mistakes, students A, B and C made the following comments in face-to-face interviews:

I feel anxious and worried while speaking English in the classroom with the fear of making mistakes, and I feel extra stressed when my friends correct me, and I get frustrated with them since they behave as if they speak English better than me. (Researcher's translation)

I sometimes feel that my teacher and friends are like waiting for my mistake by giving me strange looks, which causes me to get anxious and lose my self-confidence. (Researcher's translation)

I feel pretty comfortable in my speaking classroom and I am not afraid of making mistakes, and I think I learn from my mistakes and the feedback they — my teacher and friends - provide immediately. (Researcher's translation)

The interviewees also reported their strengths and weaknesses in EFL speaking skill. They self-reported that they were lacking in fluency, appropriate word choice, grammatical accuracy, pronunciation and intelligibility. Conversely, some others considered intelligibility, grammatical accuracy, pronunciation and accurate word choice as their strong points.

Finally, the students reported that self-assessment practices cause some level of FLSA. When asked whether they self-assess by comparing themselves with their peers, nine of the students responded in an affirmative manner, saying that they compare themselves in order to see their improvement and place among their peers and to learn from their peers. However, student D commented on the level system which clusters the students according to 
their placement test scores by claiming that this might inhibit the process of peer-learning as follows:

We were put in the same classroom according to our grades; therefore, my friends are not better than me and so I cannot learn from them. (Researcher's translation)

The students reported other factors that cause anxiety, such as making grammar mistakes, lexical deficiency and feelings of shyness.

\section{What strategies do the students use to overcome their FLSA?}

The strategies that the students employed to overcome FLSA included 'making simple sentences', 'studying vocabulary', 'speaking with him/herself in the mirror', 'participating in-class activities', 'listening to peers carefully while they are speaking' and 'feeling of comfort in terms of psychological adjustment to the classroom'. Considering the strategies and activities that teachers adopted to decrease students' speaking anxiety in the classroom, they reported that teachers were helpful in terms of making them feel comfortable in the classrooms by approaching them like a friend with a respectful and positive attitude, providing sample sentences, assigning pair-work activities, making comprehensible explanations and giving synonyms for unknown vocabulary.

What do the students think about the impact of teacher L1 background (e.g. NEST or Non-NEST) on their FLSA?

The interviewees were also requested to write about their preferences for NESTs (American) or Non-NESTs (Turkish) in speaking classrooms. Five of the students stated that they would prefer to see a Turkish teacher, as they could receive better feedback through the usage of L1 and could communicate better with a Turkish teacher through limited English in terms of intelligibility. Additionally, they thought that Turkish teachers had a good sense of humor that could motivate and comfort them when they feel anxious. On the other hand, the other five students favored American teachers in order to have better pronunciation and learn about a new culture. Furthermore, they thought that the absence of L1 in EFL classrooms might force them to speak English and improve their speaking skills. The remaining two students emphasized the importance of qualifications that a good teacher should have to help them succeed while indicating no preference for L1. During the oral interviews, students $\mathrm{E}$ and $\mathrm{F}$ expressed their preferences with the comments below:

I would like to see an American teacher in the speaking course. When speaking with the teacher, I have to force myself to keep the conversation in English even if I feel stuck and anxious. (Researcher's translation)

I think I enjoy being lectured by a Turkish teacher in the speaking class because I can get better and more comprehensible feedback from the teacher on my mistakes since we can shift to L1 whenever we need. (Researcher's translation)

\subsubsection{Interviews with Teachers}

Both the American and Turkish teachers in this study were given a written interview in order to find out their feelings, thoughts, and attitudes toward their students' FLSA. In addition, they provided responses concerning the strategies and activities that they employed in the classroom to reduce speaking anxiety.

\section{What do the teachers think about teaching speaking skills?}

Teachers were asked to assess the difficulty of teaching speaking skills compared to other language skills. While Turkish teachers considered teaching speaking as a difficult task, the American teachers did not think it was necessarily more difficult to teach than the other skills. All of the teachers emphasized that the fear of making mistakes was a source of anxiety that prevented students from producing L2 during speaking activities and resulted in a lack of self-confidence among the students. The Turkish teachers stated that teaching speaking required commitment and communication teachers should be both motivating and encouraging to reduce anxiety in the classroom. The American teachers similarly emphasized the challenge of keeping students motivated but also highlighted other challenges not explicitly related to the sources of the students' anxiety, such as explaining directions and avoiding miscommunications or false understandings.

\section{What do the teachers think about the sources of FLSA?}

The teachers generally agreed that the fear of making mistakes was a primary source of FLSA. They noted the role of peer pressure in discouraging students from speaking in front of the class. One Turkish teacher stated:

I think that speaking anxiety primarily comes from speaking in front of the classroom. Therefore, the anxiety can be reduced by seating the students in groups of 3 or 4 instead of in the classical row arrangement or in a U-shaped formation, where the teacher is, indeed, in the center of learning. (Köksal)

Additionally, some teachers noted that the students' low level of language proficiency enhanced their fear of making mistakes and general speaking anxiety, although this factor was believed to decrease as students moved 
up in language level. Furthermore, an American teacher observed that students often experienced anxiety when speaking to a native speaker for the first time, but he stated that this source of anxiety went away as the student became more comfortable with the teacher and peers in his classroom.

Teachers were asked to identify students' strengths and weaknesses that may serve as sources of anxiety or strategies to reduce anxiety. Both teacher groups focused on the prevalence of grammatical and lexical mistakes made by the students as sources of FLSA. The American teachers stated that the students' lack of exposure to L2 and the limited practice available outside of the classroom contributed to their weaknesses in producing structurally and lexically correct sentences. The lack of exposure to L2 may also serve as a source of anxiety. However, the teachers stated that despite these mistakes, the students were overall very good at expressing themselves in terms of conveying the content of their meaning, indicating that intelligibility was a strength that may diminish anxiety. Both NESTs and Non-NESTs agreed that pronunciation was not a major weakness or potential source of anxiety.

\section{What responsibilities do the teachers take to reduce students' FLSA?}

The teachers reported that they utilized a variety of strategies to reduce their students' FLSA. Both Turkish and American teachers stated that they teased themselves or consciously made mistakes to demonstrate that making mistakes was part of learning. One of the American teachers commented on mistakes as follows:

... [I] show the students despite my years of practicing, speaking, learning, and teaching English, I, too, make mistakes. I remind them that people make mistakes in their L1, so mistakes in the L2 is nothing to be ashamed of. (Tom)

Additionally, they praised students to increase self-confidence and reduce anxiety. The American teachers stated that they used other speaking activities such as games and competitions to eliminate anxiety while the Turkish teachers geared activities toward an individual student's strengths and weaknesses to overcome speaking anxiety.

Finally, the teachers reported that they attend to students' mistakes in communication classes in different manners. They presented a list of common types of mistakes and their frequency. Additionally, they provided their feedback strategies to cope with those mistakes without increasing the students' anxiety. According to the responses, students most commonly made grammatical mistakes, especially in terms of verb tense and articles. Students also frequently made vocabulary mistakes regarding word choice. The American teachers noted mistakes with pronunciation and fluency but observed that these mistakes were most common at the beginner level and decreased as the students moved to the intermediate level. Teacher correction was not appreciated as a form of feedback by any of the teachers; instead, they preferred self-correction or peer-correction as methods of feedback for oral mistakes. The teachers emphasized that they avoided direct correction, as this may contribute to speaking anxiety in the classroom. Many teachers praised the students despite mistakes and encouraged mistakes as a form of learning.

\section{Discussion and Conclusion}

This study primarily investigated the EFL students' attitudes toward and feelings about FLSA in relation to communication classes taught by NESTs and Non-NESTs. Furthermore, the present study aimed to reveal the different sources of anxiety and various strategies that both teachers and students utilize to control FLSA in the classroom.

The quantitative results of this study revealed no significant difference between students' attitudes toward FLSA they experience in classes taught by NESTs and non-NESTS. However, there was a significant statistical difference in the students' attitudes toward FLSA between the two Turkish teachers' classrooms, although this distinction was not apparent in the qualitative data. Based on Young's (1991) list of potential sources of FLSA, this can be interpreted to indicate that rather than a teacher's nationality or native language, individual factors pertaining to the teachers - teacher personality, teaching style, teacher attitude, etc. - have an impact on FLSA. Another finding which was derived from the qualitative data was that there is no correlation between students' attitudes toward anxiety and their gender, although previous studies have found that female students typically have higher levels of anxiety (Aida, 1994; Sarıül, 2000; Ngidi \& Siberya, 2003).

The results of this study are consistent with the findings of previous research in terms of sources of speaking anxiety (Horwitz et al., 1986; Young, 1990; Doly, 1991). Peer pressure, which stems from speaking in front of the classroom, and the fear of making mistakes are described by both teachers and students as the main causes of speaking anxiety. Moreover, a lack self-confidence in language abilities (Price, 1991) along with peer-pressure and a competitive classroom environment (Bailey, 1983) contribute to high levels of speaking anxiety in this study, although FLSA can be experienced at advanced levels as well (Tóth, 2011). In order to cope with speaking 
anxiety, students and teachers employ a variety of strategies that can be further studied. Both teachers and students emphasized the importance of a comfortable classroom setting to promote students' psychological adjustment to the L2 learning environment. Many teachers and students emphasized the importance of tolerating mistakes and viewing them as an essential part of the learning process.

In this study, teachers and students shared similar views on the weaknesses and strengths that students have in speaking classrooms but differed in terms of feedback strategies. Although students mostly appreciate teacher feedback on their mistakes, the teachers interviewed in this study opted for peer- and self-correction instead of giving direct feedback. Despite the teachers' preference, the interview results indicated that students dislike peer-correction which contributes to their speaking anxiety. Therefore, another implication for further research can be studying the effectiveness of different feedback strategies on students' FLSA.

\section{Acknowledgements}

We would like to express our deep gratitude to the students and teachers of Bursa Technical University School of Foreign Languages for their participation in this study. Additionally, we would like to express our special thanks to Kari Elizabeth Şahan for her invaluable support in proofreading this article.

\section{References}

Aida, Y. (1994). Examination of Horwitz, Horwitz and Cope's construct of Foreign Language Anxiety: The case of students of Japanese. The Modern Language Journal, 78(2), 155-167. http://dx.doi.org/10.1111/j.1540-4781.1994.tb02026.x

Alptekin, C., \& Alptekin, M. (1984). The question of culture: EFL teaching in non-English-speaking countries. ELT Journal, 38(1), 14-20. http://dx.doi.org/10.1093/elt/38.1.14

Arva, V., \& Medgyes, P. (2000). Native and non-native teachers in the classroom. System, 28(3), 355-372. http://dx.doi.org/10.1016/S0346-251X (00)00017-8

Bailey, K. M. (1983). Competitiveness and anxiety in adult second language learning: Looking at and through the diary studies. In H. W. Seliger, \& M. H. Long (Eds.), Classroom oriented research in second language acquisition (pp. 67-102). Rowley, MA: Newbury House.

Bozavli, E., \& Gulmez, R. (2012). Turkish students' perspectives on speaking anxiety in native and non-native English speaker classes. Us-China Education Review, 12, 1034-1043.

Braine, G. (2005). A history of research on non-native speaker English teachers. In Llurda, E. (Ed.), Non-native Language Teachers: Perceptions, Challenges and Contributions to the Profession (pp. 13-23). New York, Springer. http://dx.doi.org/10.1007/0-387-24565-0_2

Canagarajah, S. (1999). Interrogating the "native speaker fallacy": Non-linguistic roots, non-pedagogical results. In G. Braine (Ed.), Non-native educators in English language teaching (pp. 77-92). Mahwah, NJ, Erlbaum.

Carroll, J. B. (1981). Twenty-five years of research on foreign language aptitude. In K. C. Diller (Ed.), Individual differences and universals in language learning aptitude (pp. 83-118). Rowley, MA: Newbury House.

Clément, R. (1986). Second language proficiency and acculturation: An investigation of the effects of language status and individual characteristics. Journal of Language and Social Psychology, 5(4), 271-290. http://dx.doi.org/10.1177/0261927X8600500403

Cook, V. (1999). Going beyond the native speaker in language teaching. TESOL Quarterly, 3(2), 185-210. http://dx.doi.org/10.2307/3587717

Daly, J. (1991). Understanding communication apprehension: An introduction for language educators. In E. K. Horwitz, \& D. J. Young (Eds.), Language Anxiety: From theory and research to classroom implications. New Jersey: Prentice Hall.

Ely, C. M. (1986). An analysis of discomfort, risk-taking, sociability, and motivation in the L2 classroom. Language Learning, 36, 1-25.

Gardner, R. C., Lalonde, R. N., Moorcroft, R., \& Evers, F. T. (1987). Second language attrition: The role of motivation and use. Journal of Language and Social Psychology, 6(1), 29-47. http://dx.doi.org/10.1177/0261927X8700600102

Gardner, R., \& Lambert, W. (1972). Attitudes and motivation in second language learning. Rowley, MA: Newbury House.

Gregersen, T., \& Horwitz, E. K. (2002). Language learning and perfectionism: Anxious and non-anxious 
language learners' reactions to their own oral performance. The Modern Language Journal, 86(4), 562-570. http://dx.doi.org/10.1111/1540-4781.00161

Guiora, A., Beit-Hallahmi, B., Brannon, R., \& Scovel, T. (1972). The effects of experimentally induced changes in ego states on pronunciation ability in a second language: An exploratory study. Comprehension Psychiatry, 13, 421-428. http://dx.doi.org/10.1016/0010-440X(72)90083-1

Horwitz, E. K., \& Horwitz, M. B., \& Cope, J. (1986). Foreign language classroom anxiety. Modern Language Journal, 70(2), 125-132. http://dx.doi.org/10.1111/j.1540-4781.1986.tb05256.x

Horwitz, E. K. (1987). Surveying student beliefs about language learning. In A. Wenden, \& J. Rubin (Eds.), Learner strategies in language learning (pp. 119-129). Englewood Cliffs, NY: Prentice Hall.

Horwitz, E. K. (2001). Language anxiety and achievement. Annual Review of Applied Linguistics, 21, 112-126. http://dx.doi.org/10.1017/S0267190501000071

Koch, A. A., \& Terrel, T. D. (1991). Affective reactions of foreign language students to Natural Approach activities and teaching techniques. In E. K. Horwitz, \& D. J. Young (Eds.), Language anxiety: from theory and research to classroom implications (pp. 109-126). Upper Saddle River, NJ: Prentice Hall.

Kondo, D. S., \& Ling, Y. Y. (2004). Strategies for coping with language anxiety: The case of students of English in Japan. ELT Journal, 58(3), 258-265. http://dx.doi.org/10.1093/elt/58.3.258

Krashen, S. (1981). Second language acquisition and second language learning. Oxford.

Krashen, S., Long, M., \& Scarcella, R. (Eds.). (1982). Child-adult differences in second language acquisition. Rowley, MA: Newbury House.

Liu, M. (2009). Reticence and Anxiety in Oral English Lessons. Berne: Peter Lang.

MacIntyre, P. D., \& Gardner, R. C. (1989). Anxiety and Second Language Learning: Toward a theoretical clarification. Language Learning, 39(2), 251-275. http://dx.doi.org/10.1111/j.1467-1770.1989.tb00423.x

MacIntyre, P. D., \& Gardner, R. C. (1991a). Investigating language class anxiety using the focused essay $\begin{array}{lllll}\text { technique. } & \text { The } & \text { 296-304. }\end{array}$ http://dx.doi.org/10.1111/j.1540-4781.1991.tb05358.x

MacIntyre, P. D. (1995). How does anxiety affect second language learning? A reply to Sparks and Ganschow. The Modern Language Journal, 79(1), 90-99. http://dx.doi.org/10.1111/j.1540-4781.1995.tb05418.x

MacIntyre, P. D. (1999). Language Anxiety: A review of the research for language teachers. In: D. J. Young (Ed.), Affect in foreign language and second language teaching: A practical guide to creating a low anxiety classroom atmosphere (pp. 24-45). Boston: MacGraw-Hill.

MacIntyre, P. D., \& Gardner, R. C. (1991b). Language anxiety: Its relation to other anxieties and to processing in native and second languages. Language Learning, 41(4), 513-534. http://dx.doi.org/10.1111/j.1467-1770.1991.tb00691.x

Maclntyre, P. D., \& Gardner, R. C. (1994a). The effects of induced anxiety on three stages of cognitive processing in computerized vocabulary learning. Studies in Second Language Acquisition, 16(1), 1-17. http://dx.doi.org/10.1017/S0272263100012560

Maclntyre, P. D., \& Gardner, R. C. (1994b). The subtle effects of induced anxiety on cognitive processing in the $\begin{array}{llll}\text { second language. Language 283-305. } & \text { Learning, }\end{array}$ http://dx.doi.org/10.1111/j.1467-1770.1994.tb01103.x

Medgyes, P. (1994). The non-native teacher. London: Macmillan.

Mullock, B. (2003). What makes a good teacher? The perceptions of postgraduate TESOL students. Prospect, 18(3), 3-24.

Nemtchinova, E. (2005). Host teachers' evaluations of nonnative-English-speaking teacher trainees: A perspective from the classroom. TESOL Quarterly, 39(2), 235-261. http://dx.doi.org/10.2307/3588310

Ngidi, D. P., \& Sibaya, P. T. (2003). Student teacher anxieties related to practice teaching. South African Journal of Education, 23(1), 18-22.

Onwuegbuzie, A. J., Bailey, P., \& Daley, C. E. (1999). Factors associated with foreign language anxiety. Applied Psycholinguistics, 20(2), 217-239. http://dx.doi.org/10.1017/S0142716499002039

Penfield, W., \& Roberts, L. (1959). Speech and brain mechanisms. New York: Atheneum Press. 
Phillips, E. M. (1992). The effects of language anxiety on students' oral test performance and attitudes. Modern Language Journal, 76(1), 14-26. http://dx.doi.org/10.1111/j.1540-4781.1992.tb02573.x

Pimsleur, P. (1966). Pimsleur language aptitude battery (PLAB). New York: Harcourt Brace Jovanovich.

Price, M. L. (1991). The subjective experience of foreign language learning anxiety: Interviews with anxious students. In E. K. Horwitz, \& D. J. Young (Eds.), Language anxiety: From theory and research to classroom implications (pp.166-172). Englewood Cliffs, NJ: Prentice Hall.

Sarıül, H. (2000). Trait anxiety of foreign language anxiety and their effects on learner foreign language proficiency and achievement. MEd dissertation, İstanbul: Boğaziçi University.

Schwarzer, R. (1986). Self-related cognition in anxiety and motivation. Hillsdale, New Jersey: Lawrence Erlbaum Associates.

Scovel, T. (1978). The effect of affect on foreign language learning: A review of the anxiety research. Language Learning, 28(1), 129-142. http://dx.doi.org/10.1111/j.1467-1770.1978.tb00309.x

Tobias, S. (1979). Anxiety research in educational psychology. Journal of Educational Psychology, 71(5), 573-582. http://dx.doi.org/10.1037/0022-0663.71.5.573

Tobias, S. (1980). Anxiety and instruction. In I. G. Sarason (Ed.), Test anxiety: Theory, research, and application. Hillsdale, New Jersey: Lawrence Erlbaum Associates.

Tobias, S. (1986). Anxiety and cognitive processing of instruction. In R. Schwarzer (Ed.), Self-related cognition in anxiety and motivation (pp. 35-54). Hillsdale, NJ: Erlbaum.

Tóth, Z. (2011). Foreign language anxiety and advanced EFL learners: an interview study. WoPaLP, 5, 39-57.

Tucker, R., Hamayan, E., \& Genesee, F. H. (1976). Affective, cognitive, and social factors in second language acquisition. Canadian Modern Language Review, 32(3), 214-226.

Wilson, S. T. J. (2006). Anxiety in learning English as a foreign language: Its associations with student variables, with oral proficiency, and with performance on an oral test (Unpublished doctoral dissertation, Universidad de Granada).

Worde, R. V. (1998). An investigation of students' foreign language anxiety (ERIC Document Reproduction Service). Retrieved from http://www.eric.ed.gov/ERICWebPortal

Young, D. J. (1986). The relationship between anxiety and foreign language oral proficiency ratings. Foreign Language Annals, 19(5), 439-445. http://dx.doi.org/10.1111/j.1944-9720.1986.tb01032.x

Young, D. J. (1990). An investigation of students' perspectives on anxiety and speaking. Foreign Language Annals, 23(6), 539-553. http://dx.doi.org/10.1111/j.1944-9720.1990.tb00424.x

Young, D. J. (1991). Creating a low anxiety classroom environment: What does language anxiety research $\begin{array}{lllll}\text { suggest? } & \text { The Modern }\end{array}$ http://dx.doi.org/10.1111/j.1540-4781.1991.tb05378.x

\section{Copyrights}

Copyright for this article is retained by the author(s), with first publication rights granted to the journal.

This is an open-access article distributed under the terms and conditions of the Creative Commons Attribution license (http://creativecommons.org/licenses/by/3.0/). 